\title{
Normative Ethics and Sport: A Moral Manifesto
}

\author{
Jerzy Kosiewicz
}

Josef Pilsudski University of Physical Education in Warsaw, Poland

KEYWORDS

\begin{abstract}
This article constitutes a strictly cognitive and completely non-ideological moral (or rather, amoral) manifesto that makes no value judgments. The article concerns relationships that, according to sport enthusiasts with varying levels of competence, occur between sport and normative ethics. The author of this article supports a standpoint he terms ethical negationism that rejects the need for moral rules to externally support and bolster the rules of sport competition. The author assumes that the rules of sport play and competition are, and should be, completely amoral and independent from ethics. While this article is a fully autonomous ethical manifesto, it also constitutes an introduction to other articles in this issue of the journal arguing that sport competition takes place beyond the scope of moral good and evil.

The author debates value judgments commonly held by sport enthusiasts who, albeit presumably driven by noble intentions, take great effort to bolster the formal, functional, and axiological status of sport. Most sport enthusiasts claim that sport has a unique moral and normative mission to propagate intuitively understood religious and non-religious good. They argue that sport constitutes something more than sport play and competition. The author rejects this point of view and assumes that normative ethics is unnecessary because what only matters is strictly following the rules of competition (referred to as pure play) and skillfully and praxeologically (i.e., effectively) using them during play, thus working towards the assumptions and aims of a given sport activity.

sport, normative ethics, ethical negationism
\end{abstract}

\section{Introduction}

This article aims to refute opinions commonly held by sport enthusiasts who, albeit presumably driven by noble motives, take great effort to bolster the formal, functional, and axiological status of sport. Some enthusiasts claim that sport has a unique moral and normative mission to propagate intuitively understood good. They refer to their own religious beliefs and support them with concepts taken from the philosophy of religion, i.e., from those types of it that this article addresses, related to a given faith. Sport enthusiasts also refer to strictly philosophical viewpoints (unfortunately, only superficially), e.g., to Kantian ethics.

\section{Is a religious or secular ethical universalism possible?}

Sport enthusiasts of the former type draw from, e.g., Catholic personalism and underline its indisputable ethical universalism or, to put it in Kantian terms, the universality and necessity of ethical norms included in Catholic personalism. This viewpoint cannot be maintained when juxtaposed with: 
a) Values characteristic for tens or even hundreds of thousands of other religious beliefs and ideas and different moral postulates included in them, related to, e.g., soteriological ethics; and

b) The immense number of non-religious systems of beliefs and values and the corresponding recommended moral norms.

The number and independence of religious and non-religious judgments, norms, patterns, codices, models, fixed moral schemata and conventions, and other smaller or larger sets of ethical postulates, all of which underline their own unique autonomy and advantage over other beliefs, has prevented, and will always prevent, closing the distance between them and reaching unification. By the same principle, we will also never be able to develop a synthetic, emotional, and ethical denominator, i.e., necessary, common normative ethics.

The difficulties indicated above also concern rewards and penalties related to past, current, and future (not yet known, but with the potential to appear in a great number) normative ethics systems. There are as many differences in this respect as there are religious and non-religious sets of moral postulates. This makes it difficult to develop universal rules for rewarding appropriate behavior and punishing inappropriate behavior, as each religion evaluates these behaviors differently. For instance, a particular religion instructs adulterers to just say the Rosary, while another punishes them with bestial stoning. One religion punishes marrying a person from another religion only by not bestowing the sacrament of Matrimony, while another punishes this act in an extremely cruel manner, i.e., with death.

The vast number of concretizations as well as the extreme differences in evaluations, punishments, and rewards (deeply rooted in the traditions of mutually conflicting cultures) prevents us from developing their common, consistent catalog that would take into account all religious ideas and beliefs.

The plurality of normative standpoints and (especially) their mutual incompatibility and unwillingness to unify and create a new whole is made even more problematic by factually, formally, and axiologically related justification contexts. These contexts include descriptions, explanations, evaluations and indoctrination, all of which facilitate accepting, "understanding," and internalizing a given religion's dogmas and beliefs. They also strongly underline the need to strictly and consistently follow these dogmas and beliefs. Usually, in fact, they stipulate, rather than encourage, following their teachings. The aforementioned contexts are as follows:

a) The factual context, which primarily involves main assumptions included in the teachings of a given religion;

b) The formal context, which primarily involves the sources and foundations of worship and of a given religious organization;

c) The axiological context, which primarily involves supernatural traits and properties of the world and of the human nature, described in terms of theology and philosophy of religion.

In fact, each of the listed justification contexts takes into account (as far as necessary) the assumptions, arguments, and values that appear in the other two contexts. In other words, values expand to other contexts. Each of the three justification contexts is axiomatically dependent on the other two.

The aforementioned contexts originate from mythical and mythological founding deposits of a given religion and are embedded in that religion and its particular sacred values. Sacred and founding values are present, either directly or indirectly, in every religion and every religious rule concerning worship, teaching, and organization. These values also relate in a regulatory and postulative manner to the behavior of the individuals concerned. These individuals usurp the right (based on a conviction that their beliefs are irrefutable, necessary, and universal) to enforce their own values on other religions and secular populations. In fact, the three justification contexts differ in a similar fashion to moral postulates characteristic of religious beliefs and ideas and to rewards and punishments that motivate and strengthen the application of these beliefs and ideas. 
The diversity and equality of various normative religious and non-religious ethics systems and the related justification contexts prevents creating a universal code of conduct that would take into account the expectations and needs of all persons, including athletes. For persons engaged in sport, the rules of each sport discipline, as well as the general and particular administrative, civil, and criminal laws that are in force in a given country, constitute their code of conduct. The rules of each discipline are universal and cannot be deviated from. All persons engaged in sport, including athletes from different countries, must strictly follow them. In fact, rules concerning sport competition are formulated and approved by various national and international authorities, committees, associations, and federations. This is what their universality entails. Subsequently, these rules are compiled and approved (either immediately or once recommended amendments have been introduced) in national registry courts of countries in which the board of a given sport organization is registered. Therefore, the rules of each sport discipline also have legal foundations. However, as opposed to sport rules, the aforementioned types of laws are not universal. As a result, the interpretation of the laws is not universal. While rules and prohibitions are binding, penalization may differ. Pharmacological doping, which is prohibited by sport rules, can be prosecuted based on the Code of Criminal Procedure. For instance, in Italy and the United States, doping is treated as a crime punishable by imprisonment. Other countries use less strict punishments, e.g., they may penalize it with disqualification lasting a few months to a several years.

In sum, the rules of each sport discipline are universal in character. On the other hand, laws concerning sport are relativized to the code of conduct in a given country. Normative ethics is the most relative type of ethics. Developing a universal ethical code on its basis, either a general code or a code concerning sport, is impossible.

\section{Naturalistic fallacy and moral values}

It is usually assumed, based on David Hume, that one should not derive value judgments from declarative sentences about facts. This is because deriving ethics-related value judgments from descriptions of reality constitutes, from the viewpoint of the logical procedure applied by Hume, a naturalistic fallacy (Hume 1947, pp. 67-77, 1963; Jedynak 1974, pp. 157-159). Hume argued that no postulative judgments can be derived from a factual, emotionally neutral description of nature. Scholars dispute to this day whether it's at all possible to explicate purely descriptive statements from a sensory observation that would not be contaminated by value judgments (Kosiewicz, 1989, pp. 83-94).

Without a doubt, the description of how the Earth was created and two descriptions of how humans were created that can be found in Jewish myths from the Old Testament (which is also counted among founding deposits of Christianity) do not contain purely idiographic (i.e., descriptive) sentences. This is because these descriptions are, according to the believers of the aforementioned religions, saturated with divine values, as the text of the holy book was revealed to the prophets by Yahweh. From this perspective, the classical form of the naturalistic fallacy does not occur because other values, including moral norms, can be derived from the Old Testament descriptions that concern the world and humanity and that include holy values. Nonetheless, these sentences cannot be analyzed from the viewpoint of truth and falsehood in the logical sense for the following three reasons:

1. Sentences found in religious myths are not ascribed the same properties as cognitive sentences, which are instead characteristic of scientific disciplines. Mythological statements are emotional and do not fall under logical criteria. From the logical perspective, they are neither true nor false;

2. Value judgments, i.e., statements with emotional properties, derived from sentences found in myths, are also neither logically true nor logically false;

3. Statements constituting ethical norms can be logically neither true nor false because emotional norms in general (both aesthetic and ethical) do not fall under the criteria of truth or falsehood in the logical sense. 
Nonetheless, religious values, including ethical postulates (drawn from holy books as well as religious tradition), not only can be - but actually are - treated by religious communities as manifestations of indisputable revealed truth. They are a distinctive form of a certain indisputable truth that is accepted based on a community agreement approved by all concerned individuals. This agreement constitutes a binding religious convention for a given religious group. However, this religious convention, with all its sentences, does not fall under the logical criteria of truth and falsehood.

A given metaphysical (story-like and phantasmagorical) religious convention and mythical (or mythological) writings to which it is related should not form the basis for regulating social life and sport activity in a secular and democratic country. Any such convention would also conflict with many writings of other religions. Moreover, secular individuals are not and would not be interested in complying with religious rules in secular or theocratic countries.

\section{Religious philosophy and theology in the context of sport}

The aforementioned justification contexts also emerge from religious philosophy mixed to a greater or lesser extent with a theology related to a given religion.

The Protestant philosophy is an example of referring in philosophy to the theology of a particular religion and to the aforementioned biblical writings, both directly and indirectly. During the Reformation, Protestantism did not develop its characteristic religious attitudes based on the teachings of the Catholic Church. Instead, Protestantism drew directly from biblical writings. As a result, the interpretation of Protestantism and its philosophy became hegemonized by theological thought. This is why, in the case of a majority of distinguished Protestant thinkers, we witness a phenomenon termed the theologization of philosophy, which involves combining theology and philosophy under the authority of theology. Many Protestant philosophers underline that their statements are also theological in character. Jurgen Moltmann's opinions are a typical example of such an approach. As a rule, Moltmann ignores the distinction between theology and philosophy, introducing into his musings terms and categories appropriate for scriptural writing. Consequently, he considers these terms and categories as the basis for investigating the nature of the world and humanity and the resulting ethical values and postulates. Ecological ethics originating in ecological theology are an example of this investigation. Ecological ethics form a part of soteriological ethics. Moltmann assumes that striving for salvation should involve caring for nature, as the Holy Spirit inhabits it. Human nature, i.e., the body and the soul, should also be cared for, as the Holy Spirit inhabits each body and soul as well (Moltmann, 1995, pp. 27-28, 409-410; Kosiewicz, 2000b, pp. 177-192).

To a lesser extent, the influence of Protestant theology on philosophy can be seen in Wolfhart Pannenberg's (1978; Kosiewicz, 2000c, pp. 170-175) and Albert Schweitzer's (2014) views. Nonetheless, their philosophies remain considerably influenced by Protestant theology.

Another example of philosophy becoming mixed with theology is, without a doubt, the early Christian philosophy of Augustine of Hippo (e.g., "De Civitate Dei"). His philosophy is imbued to a significant degree with his apologetic theology. It includes a doctrinal vision of a new Christian church that would constitute a modern institution completely independent from the philosophy of Origen, the greatest early Christian philosopher and theologian until Augustine. Augustine of Hippo also worked towards making the Church independent from heterodoxy. In his writings, he combatted strong heretical motions and beliefs that emerged within Christianity (the end of the fourth and the beginning of the fifth centuries were indeed turbulent times for Christianity). He also argued against external religions, such as Judaism, Mithraism, Manichaeism, and other Gnostic movements. He tried to limit their influence. Furthermore, he criticized Plotinus' philosophy and Neoplatonic skepticism (in "Contra Academicos"). Neoplatonic skepticism contradicted Augustine's theory of authority based on the indisputability of revelation and biblical writings, given by God (Kosiewicz, 2000, p. 77).

Thomas Aquinas's views are also a combination of philosophy and theology, albeit to a much smaller degree that Augustine's views. This is primarily due to the fact that Thomas Aquinas contested the 
medieval concept whereby philosophy was deemed subservient to religion. Contrary to early Christian thought and ancient Greek and Roman philosophies, theology became the mother of all sciences, while philosophy was only the most important of the liberal arts. However, Thomas showed that both theology and philosophy can lead to the explanation and understanding of God's creation and the truth about it, even if through different methods. Nevertheless, Thomas Aquinas did not expand on his own assumptions and submitted to the pressure from the several centuries-long tradition that tied philosophy and theology together. This refers to a part of his voluminous, unfinished "Summa Theologiae" entitled "Treatise on Human Nature", which contains certain ethical implications (Thomas Aquinas, 1998).

Today, Catholic thought strongly differentiates philosophy from theology. In Poland, Catholic theology and philosophy involve separate academic degrees and a separate academic title of Professor. Catholic philosophy is religious (as opposed to theological) in character. It justifies and explains why personalistic assumptions, such as those made by Jacques Maritain (1965, pp. 78-84) and Emmanuel Mounier (1960, pp. 200-209, 248-252), are not only reasonable, but true as well.

A similar situation takes place in many works of the extremely creative Christian philosopher Stanisław Kowalczyk, whose works also present and justify Catholic beliefs, but without using a theological argumentation. Kowalczyk makes a clear division between philosophy and theology, as can also be seen in his monograph entitled Elementy filozofii i teologii ("Elements of Philosophy and Theology of Sport") (Kowalczyk, 2002).

However, it is worth indicating that in his statements about sport activity, Kowalczyk professes the (in a sense fundamentalist) need for athletic behavior to fall under ethical assumptions characteristic for Catholic personalism. Years ago, Jerzy Cygan (1993, pp. 17-18, Kosiewicz, 2004, pp. 128-129) warned against such a viewpoint, which contemporarily is decidedly non-religious and multicultural, as well as against enforcing a religious perspective upon persons engaged in sport.

Cygan argued that as far as the relationships between sport and Catholicism and between sport and Catholic theology and ethics (and even between sport and other religions) are concerned, one should always take into account the widespread secularization of the world. He indicated that this issue:

"was addressed in detail by W. Kuchler at the beginning of the 1970s" (Cygan, 1993, p. 17).

Kuchler was an accomplished Catholic philosopher who

"emphasized the need to develop theological thought concerning sport" (Cygan, 1993, p. 17).

However, Kuchler underlined the autonomy of sport in relation to the Catholic Church and Catholic theology. "Kuchler concluded that the Church, i.e., its authorities and priests, have a positive approach to sport, just as to all other realities, and that 'preaching by faultfinding' has been all but eradicated" (Cygan, 1993, p. 17). He also stated that:

"the value of sport and its ethos is limited. Any hopes of and attempts at Christianizing sport as such are unrealistic. Religious guidance has a much smaller potential in this respect. Interpreting sport as such in the Christian way would even be undesirable. Sport ethos belongs naturally to this world and can morally transform the realm of sport relationships, but is unable to solve crucial life issues, such as introducing order to all areas of life or maintaining health. Sport ethos is neither a reflection of Christian life nor a natural model of Christian life (...) Sport and sport ethos should not be accompanied by treating sport as a 'tool for preaching' that can be used to achieve a particular goal, e.g., creating disciplined Catholics" (Cygan, 1993, p. 17).

Cygan adds:

"In truth, there exists no such thing as Christian sport, as there is no Christian method of throwing a ball or a discus. The rules of play should be maintained. No sport discipline is more or less Christian than others. Fair play, honesty, bravery, moderation, and numerous 
other virtues are not specifically Christian; rather, they belong to elementary human ethics".

(Cygan, 1993, p. 15)

The quoted viewpoint clearly indicates:

a) That making athletes follow certain all-important and glorious moral aims related to any religion or any non-religious norms that extent beyond the sport environment is excessive and contradicts sport values, as "the value of sport and sport ethics is limited" (Cygan, 1993, p. 17);

b) That Catholic theology and Catholic normative ethics should not interfere in the rules of individual sport disciplines, rules of competition, moral ethos, and all aspects of life of persons belonging to the sport environment.

On a side note, it would be difficult to, for instance, suggest that during a fighting match, two boxers, one a Shinto believer, the other a radical Shiite, cultivate Catholic ethics (or any other religious normative ethics) that they know nothing about and that contradict hallowed moral rules and deposits of their faiths. Rather, we should concentrate on athletes' compliance with the rules of a given discipline, which do not contain any ethical normative statements.

\section{Ethical verticalism and sport activity}

The biblical, religious, theological, and philosophical approaches presented in the preceding sections of this paper that concern the origin of moral values and their relationship with sport can also be analyzed from a verticalistic viewpoint.

On a side note, I use the term ethical verticalism, taken from the philosophy of morality, in a broader as well as narrower sense (thus, the philosophy of morality can be examined, on the one hand, as ethics, i.e., one of the main branches of philosophy, and on the other hand, as an analogon of meta-ethics or metamorality, as opposed to descriptive ethics and normative ethics). Ethical verticalism, just as all the aforementioned (broadly defined) religious and philosophical standpoints, can be examined in the light of issues characteristic for the sociology and psychology of morality. However, when examining ethical verticalism, I will apply factual and formal assumptions characteristic for philosophy, as in the preceding sections of this paper.

Ethical verticalism involves a vertical moral relationship that takes place between man and a supernatural being. Human beings feel an intuitive, direct unity with values coming from perfect beings. Humans can then perceive instructions about their duties towards the Supreme Being and towards social and ecological niches, and learn the scope and essence of soteriological duties. These instructions are given from top to bottom.

Thus, ethical verticalism assumes (in the formal sense) a different type of a moral relationship, i.e., an ethical links between entities, and a different source of values and duties than ethical relationism. In ethical relationism, moral links are horizontal.

Ethical verticalism comprises two approaches: the transcendent approach and the transcendental approach.

1. The former relates to a particular religion and its philosophy. Therefore, the following types of ethical verticalism can be distinguished:

a) Strictly religion-oriented ethical verticalism, which states that, e.g., God is the source of normative ethics and it is God who provides (any time He wishes and in any manner He wishes) necessary moral instructions from top to bottom. Abraham was among those who received such instructions (they were given to him by Old Testament Yahweh through an archangel on Mount Sinai). These particular instructions constituted one of the most demanding tests of faith in God's soteriological ethics. Abraham completed the test successfully. This prompted Søren Kierkegaard to call Abraham a knight of faith, willing to sacrifice everything he held dear to God, including his own son 
(Kierkegaard, 1972). Kierkegaard canceled his betrothal to his beloved Cordelia because he also wanted to deserve such a title (Kierkegaard, 1982, p. 515).

God may also reveal His moral instructions to an entire community at once, as was the case with Yahweh, who gave the Ten Commandments written on two tablets to the chosen people.

2. Ethical verticalism present in religious philosophy, exemplified by Augustine of Hippo's standpoint on direct grace (related to illuminism): God bestows grace whenever He wishes and on whomever He wishes (even an evildoer or a harlot). This specific revelation shows the path to salvation and holiness. In other words, it reveals rules of behavior characteristic for Christian soteriological ethics. The latter approach, i.e., the transcendental approach, relates to non-religious philosophy, i.e., independent philosophy, exemplified by the views of such philosophers as Plato, Kant, and Hegel.

a) Plato's ethical verticalism assumes that a human can intuitively and directly learn the idea of good and consequently arrive at particular moral duties. Ideas from the plane of eternal ideas can inspire the human to extraordinary actions (which may even be called insane, in a positive sense of the word), i.e., inspired actions, including actions within the scope of normative ethics.

b) Ethical verticalism, as a vertical moral relationship, can also clearly be seen in Kant's justification of the metaphysics of morals. Kant refers to a transcendental "starry skies above me," i.e., the supernatural (noumenal) world. In other words, he refers to God and pure intelligences that are the source of common and necessary moral norms, the categorical imperative, and other assumptions of states of ends. The human (a bipartite entity) can access these intelligences as their carrier by means of the human mind ("the moral law inside me"). In contrast, the body cannot act as a carrier, as it cannot cross the borders of the phenomenal (sensory and natural) world.

c) Hegel, in turn, claims that morality, as a manifestation of mass consciousness, is in reality an exteriorization of the needs and properties of the Absolute. The Absolute strives (even though it does not have to, as it is by itself perfect) towards self-realization and self-affirmation. It becomes real and confirmed as an objective spirit primarily in individual and social consciousness. Humans think that it is they who create the state, law, history, religion, philosophy, culture, and morality through their consciousness, while in fact, there exists a thought that thinks within humans. Humans think that they are autonomous creators, possessors of individual consciousness, and co-creators of mass consciousness. In reality, however, it is in individual and mass human consciousness that the Absolute objectifies and evolves its own properties. Therefore, moral considerations, together with normative ethics and all its different (individual and mass) concretizations, are given by the Absolute; in fact, these concretizations are the Absolute, a constantly developing manifestation of ethical evolutionism (in broader terms called idealistic evolutionism). Thus, the Absolute provides humans with all manifestations of morality. As in the case of Plato's and Kant's philosophies, we are dealing here with a non-religious, strictly philosophical ethical verticalism.

It appears that ethical verticalism, both transcendent and transcendental, is founded upon emotional intuitions (religious, theological, and religious-philosophical) and intellectual intuitions (e.g., those of Plato, Kant, or Hegel). One cannot indisputably state that the normative ethics created by means of this intuition is necessary and universal based on these forms of intuition. In this context, the potential morality related to sport will also be intuitive and, consequently, subjective, relative, and not subordinate to any intersubjective verifiability or falsifiability.

Ethical verticalism indicates that neither normative ethics drawing from religious values nor an independent philosophy of morals (i.e., independent from any religion, ideology, policy, etc.) leads in the practical sense to ethical universalism. In Plato's case, we are dealing with different, multiplying systems of moral rules that refer to a variously defined idea of good, while in Hegel's case, we witness constant changeability of moral norms, i.e., an ethical evolution. This changeability did not cease after Hegel's death. In turn, Kant's ethics are internally inconsistent and contradict universality and necessity, thus leading to moral relativism (this reasoning is explained further in this paper). With the above considerations in mind, 
one could state that no permanent rules of moral conduct in sport are possible or necessary. No normative ethics (neither general nor particular) can substitute the rules of a given sport discipline. Moreover, the rules of competition within each discipline suggest that the potential moral attitudes would be contradictory, i.e., pluralistic, relativistic, and chaotic.

\section{Kant's categorical imperative: universality and necessity or ethical relativism}

Philosophers attempt to overcome ethical pluralism and relativism (as well as the potential ethical chaos and ethical anarchism) using rigorous solutions that do not accept other moral viewpoints. This concerns the aforementioned religious philosophy (that uses, e.g., the ethics of Catholic personalism to a greater or lesser extent related to theology or not at all related to it) as well as non-religious philosophy that refers to, e.g., ethical assumptions described in "Kant's Critique of Practical Reason" and "Groundwork for the Metaphysics of Morals".

Kant's categorical imperative is in this case wrongly given as an example of reliable foundations that formally and axiologically eliminate the ambiguity of normative ethics. The imperative is as follows:

"Act so that you use humanity, as much in your own person as in the person of every other, always at the same time as end and never merely as means" (Kant, 2002, p. 151).

However, Kant himself unexpectedly introduces a giant breach in this rule: he disputes its universality and necessity by relativizing it and negating its absolute character in the case of criminals who break criminal, administrative, and civil laws. In a footnote to his second commentary about the imperative in question, he states that a criminal could implore representatives of law to not act in a way they find repulsive, i.e., to not treat the criminal as means to achieving ends pertaining to their profession and accepted by the society. Kant also writes that:

"the criminal would argue on this ground against the judge who punishes him, etc." (Kant, 2002, p. 48).

Kant assumes that if a criminal (regardless of how serious the crimes he or she commits) does not, during his evil acts, treat others, i.e., his or her victim, in an autotelic manner (as an end in itself), but rather only as a means of realizing own needs, then the categorical imperative no longer applies to himself or herself.

Thus, Kant establishes a clearly indisputable primacy of law over normative ethics, i.e., over the form of ethics that he himself claims is necessary and universal.

From this point of view, criminals should always be treated as a means to achieving social ends (grounded in law), never as an end in itself. The metaphysical justification of morality and the corresponding categorical imperative that stem from God and pure intelligences are less important than human law that exists in different forms throughout the society.

If the categorical imperative cannot be used in a state of ethical ends in an absolute manner, then, in fact, we are dealing with moral relativism. The imperative depends not only on a single, universal set of criminal, civil, and administrative laws (as this would be impossible), but also on numerous legal codices, including extremely undemocratic ones, that differ greatly between themselves (this was especially true in Kant's times). The categorical imperative may or may not include a given moral norm depending on the law in force in a given state of amoral legislation. A given moral norm (e.g., prohibition against incest) may be treated as universal and necessary, and breaking it may be penalized by criminal law. A different moral norm may allow incest from both the moral and the legal standpoints. The state authorities and the laws they issued are the deciding factors here (viz. J. Kosiewicz, 2000a: R. Girard, "Źródła religii i kultury", pp. 39-62 (Sources of Religion and Culture)), while the moral postulate (the categorical imperative) is secondary to the law and relies on opposing points of view. Suspending the imperative depending on various legal arrangements leads not only to ethical relativism, but also to potential moral chaos. Something considered moral in one country may be a crime in a different country and a virtue to be emulated in yet another 
country. For instance, in Catholicism, having only one wife is the legal norm as well as an ethical categorical imperative. In contrast, polygamy is allowed both legally and morally in Islam, but is not and cannot be a categorical imperative because not everyone can afford multiple wives.

Another dependency of law manifests itself here. The categorical imperative in the narrow definition may involve only moral norms and behaviors that are not legally prohibited in a given country. The imperative is universal and necessary to a limited extent (as was the case for, e.g., doping of athletes in the German Democratic Republic and in the Soviet Union). The categorical imperative in the broad definition involves, from Kant's point of view, only ethical norms that do not conflict with the laws of all democratic and non-democratic countries during his time. This indicates that Kant understands and interprets these norms in a positivistic manner.

A suspension of this kind may lead to neutralization, i.e., to foregoing any use of the imperative, as crime can be relativized and understood differently and have varying forms and implications depending on culture, civilization, needs, situation, and social circumstances. On the one hand, killing a person may be treated as a violation of the categorical imperative, and on the other, totalitarian legislators may deem it a necessary act that brings desired and expected outcomes. Consequently, one may conclude that anyone who suspends this imperative in relation to another human at the same time suspends it in relation to himself or herself and can thus be treated instrumentally and punished.

In fact, treating others as a means to the desired ends does not have to be morally reprehensible at all. This phenomenon is common in almost all production processes and in professional sports, Olympic sports, or show sports.

Another of Kant's "justifications" of the imperative in his Groundwork of the Metaphysic of Morals comes from a strong belief that a noumenal world exists. The justification is insufficient, as it is based on the need to prove the existence of higher, i.e., pure, intelligences (including the Christian God). Doing so is impossible from both the scientific (including empirical) and philosophical viewpoints.

Imbuing praxeological rules, including rules of competition in sport, with moral norms would be a factual and formal error because normative ethics is completely external in relation to formal rules. This is because formal rules involve instrumental (rather than autotelic) criteria of the effectiveness of actions. Moral considerations are an external interpretation in relation to what is autonomous. Moral interpretations may vary depending on the individual, such as a review of a play written by theater critic.

\section{Sources of moral values and ethical negationism}

Justification contexts that result from independent philosophy may refer to not only ethical verticalism, but in fact to other properties of independent philosophy as well, i.e., traditional and contemporary schools, circles, directions, motions, and theories. They may also include other concepts of sources of moral values, i.e., objectivism, universalism (other than Kantian or Catholic-personalistic), relationism, relativism, rigorism, subjectivism, and situationism. The definitions of some of these sources overlap in a similar manner as verticalism overlaps with objectivism, universalism, and moral rigorism.

These philosophical standpoints have been variously characterized and justified. Nonetheless, it's worth presenting even a brief overview of how they relate to moral norms, followed by a description of the relationship between these standpoints and ethical negationism. With this goal in mind, it can be indicated that:

a) Ethical objectivism assumes that moral values exist independently of humans. Plato claimed that in the world and hierarchy of eternal ideas, good (moral good) occupies the highest position. In religion, Moses' tablets are an example of objective moral directives. From this perspective, moral rules concerning athletes and the entire sport environment may also be objectivistic. I do not share this opinion, as it derives neither from philosophy nor from religion, but from a multifaceted, socially dependent common thinking. 
b) An example of a philosophically justified moral universalism is Plato's idea of good, as opposed to the aforementioned Kant's approach and the Catholic-personalistic approach. Plato's outdated idea of good is universal (only) in the sense that all ethical concretizations that aim to achieve any, variously defined, good draw from it, including all possible moral exteriorizations concerning sport. In fact, many faiths, including Catholicism, professes the intolerant viewpoint that the normative ethics related to a given faith is universal and encompasses the entire humanities and human race, and that other faiths should accept the assumptions, detailed beliefs, and values of this ethics.

However, ethical universalism is impossible to achieve in practical, religious, and philosophical senses. This includes sport, Olympism, and the related moral norms, which have undergone constant transformations and exposition to religious, political, and ideological influences. At the beginning, i.e., in the Hellenic period, the Olympic Games were religious in character. Next, in late Roman antiquity, shortly before their abolishment, they were conducted to create a show and became athletic and gladiatorial in character, incompatible with the rules of Christianity at the time. For a long time, thanks to Pierre de Coubertin, modern Olympic ideas apotheosized religiosity, i.e., the divine, extraordinary, pan-human character of the Olympic Games. Venues of the Olympic Games became secular temples of sport. The opening and closing ceremonies transformed into extremely solemn and expensive manifestations of new, secularized forms of cult in the broad, religious sense.

The apparent universality of and unity in celebrating the Olympic Games and striving to achieve success were imbued with controversial moral rules. Initially, the Olympic Games could only be accessed by those who did not earn their living through sport. Only wealthy individuals who could afford to cover the expenditures on their own would participate. Women were not allowed to participate, but successfully fought for their rights later. Nevertheless, even today, many countries and religious societies do not guarantee the equality of moral and non-ethical rules between men and women. Universalistic moral postulates concerning Olympic ideals are not universally followed.

For several decades, supporters of the modern Olympic spirit considered professional sport as morally harmful. Later, they abandoned this controversial and paternalistic moral viewpoint, but not before hurting or disqualifying many excellent and talented athletes.

In all probability, the same will occur for the use pharmacological doping to achieve better results, as long as it is harmless to health. Pharmacological measures have been applied in medicine for ages. Drugs that strengthen an ailing body or stimulate it to survive or achieve better physiological and psychological results are commonly recommended and applied. So far, the fight against doping has involved nothing but archaic and dishonest tilting at windmills. The fight, in my opinion, is doomed to fail against the notion of controlled pharmacological support and medical stimulation of athletes' bodies to perform better.

c) Moral relationism assumes that ethical postulates originate from and develop within interpersonal relationships, including sport relationships. Ethics related to sport originates within the sport environment. They do not concern sport rules or any behavior motivated by them. They are a sociological viewpoint characteristic for an independent sociology of morals.

d) Ethical relativism assumes, in short, that all moral postulates are relative, including those related to sport. I examine this notion in more detail in other sections of this paper.

e) Moral rigorism, which dates back to as early as the sophists and Protagoras (who had close connections to them), indicates that the particular rules of ethical conduct are absolute and do not allow for exceptions. These include religious fundamentalism, Socrates' theory of moral virtues, Thomistic ethics, and Kant's categorical imperative. Anachronistic rigorists in the sport environment constitute persons who claim, for instance, that the notion of fair play is the highest value in sport.

f) Ethical subjectivism assumes that man is the only source of moral values and that it is man who creates and interprets them. This also refers to moral views on sport. It is a form of moral relativism. 
g) Ethical situationism states that moral behavior depends on a particular situation one or many individuals are in and that even strict rules of conduct can be changed depending on the circumstances. A particular form of ethical situationism that overrides rigorism and the strict paternalism of Catholic ethics is the notion of Christian prudence, which recommends suspending supposedly absolute moral rules in special cases. Ethical situationism finds application in sport. For example, it manifests itself in tactical fouls (good fouls) (viz. Kosiewicz, 2011, p. 42). Ethical situationism is a form of ethical relativism.

The aforementioned ethical negationism is a new term I have applied. It is connected to the philosophy of morality understood both broadly and narrowly (i.e., one may understand the philosophy of morality as, on the one hand, ethics and treat it as one of the main branches of philosophy, and on the other hand, as a notion identical to meta-ethics or meta-morality). Ethical negationism does not negate the existence of ethical norms that affect the fate of individuals and entire societies. Rather, it may only deny the purposefulness of their existence. Thus, ethical negationism also does not deny the need to address ethics in general from the perspectives of philosophy, sociology, psychology, and religion. Ethical negationism is a narrowed-down term. It refers only to a specific, limited part of normative ethics related to sport. It negates the need for an external support or enhancement of the rules of particular sport disciplines and rejects the introduction of moral rules into sport competition. Ethical negationism assumes that the rules of sport games and competition should have a completely amoral character, independent from ethics. Consequently, analyzing sport events in the light of various ethical postulates that are external in relation to sport, albeit possible, is pointless and fruitless.

Variously interpreted rules of fair play without a doubt constitute an example of ethical pluralism, relativism, and negationism. Five (Kosiewicz, 2010, pp. 21-25) or even six (Kosiewicz, 2011, pp. 82-85) such interpretations can be named. Their ambiguity undermines the validity of their postulates. It is indicated that:

a) The notion of fair play is the greatest value in sport and the greatest value of Olympism. In this case, the value of morality is raised, and it is assumed to have a dominant function in relationship with sport. Under this approach, sport (i.e., play and competition) seems to be a secondary value, subordinate to morality, because sport should first and foremost carry ethical norms;

b) The notion of fair play constitutes not only the foundation of sport activity, but also the basic rules of behavior that is binding in all forms of American life;

c) It is still considered important both for top level sport and sport for all, albeit its importance has visibly decreased;

d) Fair play is something more than an anachronistic, gentlemanly, Coubertin idea;

e) It is an anachronistic legacy of Don Quixote and noble yet naive and Utopian values proper for the $19^{\text {th }}$ century and the times of Coubertin;

f) Moral values are generally external in relation to sport. They are not connected with the rules of any particular sport discipline. Rather than ethical norms, only praxeological (pragmatic, utilitarian, and practical) entries are introduced into the rules. It is indicated that sport functions outside moral good and evil (Kosiewicz, 2010, pp. 21-29), including outside the notion of fair play. The notion of fair play, together with other assumptions of various normative ethics, including other ideological, political, or nationalistic values, is sometimes enforced externally, mainly due to different axionormative interests and autotelic and instrumental viewpoints. In conclusion, rather than the value of fair play, sport involves the universally amoral rule of pure play. This rule stipulates taking into account (Nota Bene under different interpretations) the rules of competition (viz. Kosiewicz, 2011, p. 42).

The latter standpoint constitutes, in fact, the approach of ethical negationism towards sports. 


\section{Pluralism, relativism, and moral chaos}

It should be indicated that the main source of moral rules in atheistic and free-thinking enclaves, both in the pre-philosophical era and the later era filled with scientific thought and philosophy, is common thinking. Individual and social moral rules have spontaneously developed within common thinking. They reflected viewpoints concerning good and evil characteristic for these enclaves. Justifications were proposed for the sense and need of conforming to those at once emotion-based and autotelic values in a widespread and common sense manner. Subjective views and relational postulates were brought up that aimed to achieve consistency and variously defined social good. Common thinking, apart from religious needs, is the most widespread source of moral norms and context in which they manifest themselves and are being justified. Common thinking has greatly contributed to the development of ethical pluralism and relativism.

The aforementioned ethical pluralism, the related diversity of normative standpoints, and the resulting ethical relativism are not interpretational postulates, but instead an expression of the actual state of affairs.

Giving the names ethical pluralism or ethical relativism to the enormous number of actually uncountable and differing standpoints within normative ethics is only mostly accurate. However, at the same time, these two terms are insufficient, as they do not adequately reflect the current state of affairs and the diversity it shows. Without a doubt, we are not dealing only with a pluralism of normative standpoints. One should also take into account the diversity of religious roots and viewpoints, the diversity and changeability of cultural and civilizational contexts, and the moral postulates that originate from them or refer (i.e., are relativized) to them, in addition to taking into account their sheer numbers.

Philosophers, sociologists, and psychologists of morality systematize all these elements, analyze them quantitatively, and determine relationships between them. While this is a useful endeavor, it may also be harmful and lead to the distortion of ethical reality. The living, complex moral phenomena with their assumed imponderabilia are being simplified and artificially analyzed: on the one hand, they are uniformized and generalized, and on the other hand, excessively subjectivized and relativized, in addition to being frequently examined from a common sense viewpoint. Consequently, Henri Bergson's controversial view may to some extent become justified whereby it is pointless to use rationalism and the related apotheosis of rational cognition as tools for achieving reliable cognition.

Moral pluralism and ethical relativism do not fully describe the qualitative properties of moral phenomena. This is because we are dealing primarily with a spontaneously spreading and independent (also from past and present postulative solutions) moral chaos, i.e., an uncontrollable chaos within normative ethics. Based on this chaos, it is indicated that moral norms, as emotional and evaluating statements, are neither logically true nor logically false, are not cognitively binding, and can be differently and relatively understood and interpreted.

Moral chaos exists regardless of attempts to explain different tendencies and opinions and to find common ground between them. This is because we are dealing with the unending appearance of new normative concepts and rules in ethics that do not refer to any common (methodological as well as axiological) arrangements, i.e., to a single indisputable benchmark or a defined, universal, approved common denominator. As in the case of formal logic, it is impossible to achieve a consensus, i.e., accept a single, universal convention, when creating emotional postulates and sets of moral rules. Ethical chaos is the predictable, rationally impossible to explain, and surprising diversity, multi-directionality, and inconsistency (more or less pronounced) that appears within the evaluations, norms, models, codices, conventions, and schemata of moral conduct. Ethical chaos is permanently rooted in moral needs, aspirations, and phenomena. Any attempts to consciously or subconsciously organize it will most likely fail. Paradoxically, each past and present standpoint emphasizing the validity of a given moral universalism confirms the existence of not only ethical pluralism, relativism, and chaos, but perhaps of anarchy in normative ethics as well. This viewpoint also includes moral postulates concerning persons engaged in sport. 


\section{Ethical anarchy and sport}

Ethical anarchy involves rejecting current, affirmed, and applied (by various social institutions) moral values and undermining and disorganizing the ethical order motivated by these values (as is the case for proselytism). Furthermore, it involves the expansion of various churches and totalitarianisms. Such moral conventions limit individual freedom.

Ethical anarchy may take either of two forms: radical or moderate.

1. The former involves the rejection of any moral values as restrictive and limiting human freedom. This form is similar to amoralism (immoralism).

2. The latter form accepts the need for ambiguously defined moral solutions appropriate for various social groups to exist independently from senior institutions.

This form is not a manifestation of amoralism, i.e., it does not profess the needlessness of any moral rules, nor is it a manifestation of moral insensitivity.

Moral anarchism can be examined from two perspectives based on the laws in force:

a) In its moderate form, moral anarchism assumes the possibility of presenting and proposing (but not enforcing) new (or other) postulative solutions, regardless of any existing standpoints, arrangements, and attitudes. It states that new proposals involving value judgments, even highly controversial proposals that negate the existing moral order, are equally as viable as norms already in force. Moral anarchism assumes that in ethics, all moral solutions are possible as long as they do not contradict the administrative, civil, and criminal laws of a democratic country. In this approach, moral anarchism is loyalist in character, i.e., it posits the superiority of legal regulations over ethical norms.

b) On the other hand, the second approach claims that normative ethics should not, when destroying old moral conventions and creating new ones, take into account the existing legal regulations within social institutions. Consequently, the existing ethical convention and the laws in force can penalize this ethical attitude.

A side note: the former, moderate form of ethical anarchism could be accepted by those who support the idea that the presence of moral norms should exist in sport, but not by the supporters of moral negationism. The latter, radical, form could not be accepted by either group of supporters.

\section{Ethical reorientation, evolution, and revolution}

The appearance of new moral solutions that completely undermine the existing moral order is also related to social changes. This phenomenon first involves a slow but constant social reorientation and a related ethical reorientation and (albeit not always) moral evolution. Secondly, it involves a rapid social revolution and the related ethical revolution.

Early Christian morality is an example of a slow ethical reorientation. Nascent Christianity ethically reoriented a majority of the ancient Roman society. It completely and consistently rejected and marginalized ancient Roman religions and Judaism. Christianity grew in strength so much that in the fourth century CE, it acquired the status of the state religion. As a result, the sport ethos changed together with an Olympic tradition of over a millennium. The moral ethos of Christianity opposed physical fitness and stipulated ascetics. It focused on perfecting the soul and leading a devout life by following religious commandments, i.e., carrying out particular soteriological ethics.

Moral evolution involves a constant development, concretization, and modification of initial moral assumptions. The core of these assumptions, termed normative ethical core, i.e., the basic, initial, and stable assumptions, remains unchanged. An example of such a core is a concisely and clearly defined moral ethos, accepted by a given community. In contrast, justification contexts derived from social conditions undergo modifications. Puritan ethics, which helped create and maintain a positive attitude toward human labor, is 
an example of moral evolution. The ethos of labor became the core of this ethics: its permanent axis as well as the driving force behind social development. It is primarily the justification contexts related to this ethos that would change. Puritan ethics exists to this day. Its core, i.e., the ethos of labor, has become the basis for middle-class morality models, such as Franklin's self-made man (a person who owns everything they achieved to their own labor) the well-rounded man, and the outwardly contained man. The ethical core (appreciation of labor) remains unchanged, while justification contexts have undergone transformations due to political changes followed by economic change.

Another example of ethical evolutionism is Hegel's philosophy of morality, which stems from idealistic evolutionism. At the same time, it exemplifies non-religious moral verticalism.

The bourgeois revolution in $17^{\text {th }}$-century England (and in $18^{\text {th }}$-century France) and the Bolshevik Revolution in $20^{\text {th }}$-century Russia constitute clear examples of social revolutions and concurrent ethical revolutions. These social revolutions were accompanied not only by moral anarchism, but also by genuine ethical revolutions that resulted in:

a) Rapid changes in moral norms, as was the case for 17th-century England, or

b) Changes that violently rejected the existing moral order, as was the case in 20th-century Russia.

The bourgeois revolution in England sanctioned the ethics of the rising capitalism that was primarily based on Protestant morality, especially on Puritan ethics. The theory of predestination was accepted as viable. As a result, moral commandments concerning heavy labor, acquiring wealth, and leading a frugal and devout life were adjusted to it. Material wealth achieved through one's own effort would indicate God's approval of one's honest, hard, and fruitful work. God rewarded following moral rules (Weber, 2011; Ossowska, 1985, pp. 184-225). As Maria Ossowska writes:

"The rush to acquiring riches also characterized Puritan denominations that did not accept the predestination dogma" (Ossowska, 1985, p. 213).

She adds that:

"The thesis that Puritan ethics in England, the United States, and the Netherlands contributed to the development of capitalism in the $17^{\text {th }}$ and $18^{\text {th }}$ centuries is rarely questioned, even though various scholars ascribed different importance to this factor" (Ossowska, 1985, p. 213).

Furthermore, Ossowska indicates that, according to Max Weber, Calvinism also

"contributed to the development of capitalism by motivating the acquisition of wealth and suppressing the traditional misgivings related to it" (Ossowska, 1985, p. 215).

Capitalism also developed thanks to the introduction of democratic and secularized social rules and the spread of the first middle-class morality model, popularized by Benjamin Franklin. This model secularized Puritan ethics and created a foundation for the future self-made man model (Ossowska, 1985, p. 78). Franklin's model spread throughout nearly the entire Western and Central Europe and the United States (Ossowska, 1985, pp. 74-118). It later developed into the well-rounded man concept, i.e., a gentle person who is polite to their superiors and potential clients, and into the outwardly contained man, i.e., a person sensitive to appropriate stimuli who is able to correctly interpret the needs of their superiors and strives to satisfy their client's needs in an optimal manner.

The behavior and attitudes of contemporary professional athletes most closely resemble, albeit with certain significant differences, the self-made man model, as the most successful athletes represent this ethos in the true sense of the word. They owe their success to their personal engagement and many years of hard work at the expense of their health and family comfort. Even if they inherit fortunes or noble titles, the amount of physical and mental effort, their perseverance, and future success in sport all depend primarily on 
each athlete's individual motivation and diligence. Their political and religious orientations, family background, nationality, and skin color generally play no role here.

On the other hand, the Bolshevik Revolution radically and immediately forbade any religious activity. It rejected religious moral rules characteristic for the Russian Eastern Orthodox Church and other faiths and imposed a model of communist morality that assumed the priority of a totalitarian and authoritative ideology over the needs and aspirations of individual citizens. The primary goal of this ideology was realizing the Utopian myth of a wholly secular country with absolute social equality, in which the expectations of all citizens could be met based on the "each according to his need" principle. Those who questioned the viability of this communist social project were treated as class enemies and imprisoned or executed.

Authoritative and totalitarian countries also considered their internal and external policy and communist ideology as governing the behavior of competitive athletes, Olympic athletes, and show sport athletes. By twisting Coubertin's ideas, the countries promoted the superiority of amateur sport over professional sport. They demanded high-level professional engagement in competitive sport, but in financial terms, treated professional athletes as amateur athletes. This refers to all periods of development in all socialist and communist countries. Sport, e.g., during the Cold War, was to show the superiority of socialism and communism over capitalism in areas where the political economy continued to fail. Sport and moral behavior on the part of athletes from "the leading socialist states in the history of mankind" had to follow this aim in an absolute manner.

Ethical revolutions lead to a moral rigorism that limited or even eradicated ethical freedom. Nonetheless, ethical rigorism unintentionally created and strengthened the need for ethical freedom to exist. Thus, moral liberalism and ethical relativism were established, leading to moral chaos and potential ethical anarchy. Ethical anarchy is the final effect of a constant strive for changes (e.g., in the form of moral reorientations, ethical revolutions, and moral revolutions) based on new needs, tendencies, and hopes. This is because there exist no rules (either permanent or temporary) for formulating ethical norms. Ethical norms are created by means of intuitive urges that consciously or subconsciously draw from new social trends and expected directions of changes.

The definitions of moral liberalism, ethical relativism, moral chaos, and ethical anarchy allow one to state that these phenomena do not preclude the existence of different-sized societies which would carry out moral rules that only these societies accept and cultivate and that benefit establishing particular positive social relationships, thus alleviating cultural and non-cultural tensions.

These moral rules should be applied by a given society as long as they benefit its functioning and enrich its civilizational and axiological identity but are not forced upon other enclaves that follow different rules and values.

One should not peremptorily dictate what rules are better than those already applied by other societies as long as the latter do not conflict with the broadly understood law (administrative, civil, and criminal as well as national and international) and do not harm their supporters. Teaching a moral viewpoint shows signs of aggressive moralizing. It may even lead to a clash of values and initiate social conflicts on varying scales.

Moralizing may even appear consciously or unconsciously in science in cases where certain ethical values are considered better and more worthy of implementation than other values. This phenomenon concerns, e.g., sociological, psychological, and pedagogical studies or even philosophical statements. If some values are considered better than others within a scientific procedure, e.g., in the sociology of morality, a statement about scientific ambitions becomes an expression of an evaluating attitude instead of a rational cognitive activity. It becomes an emotional reflection that cannot be analyzed from the perspective of logical truth and logical falsehood. In such a case, the statement is neither true nor false, even though it may be considered as being either (from the perspective of everyday thinking) by a larger or smaller group of people. The statement may be treated as a norm regulating professional activity (deontological ethics), sport activity, 
or behavior among peers or within one's family. Its superiority over other ethical norms cannot be rationally and logically substantiated from the viewpoints of a general methodology, any particular methodology, or axiology.

Research on sport, especially the role of fair play, usually does not distinguish (especially as far the first four aforementioned standpoints are concerned) describing and explaining ethical values from indoctrination. Representatives of the first two standpoints mainly engage in a radical propaganda of their own irrational, emotional viewpoint. Representatives of the subsequent two standpoints do the same, albeit in a more moderate manner. In each case, we are dealing with more or less pronounced moralizing. Unfortunately, the supporters of the aforementioned standpoints don't seem to realize than this is not the way to perform science as such.

\section{Summary}

Any musings, including those presented in this paper, that are free from any value judgments within meta-ethics and descriptive ethics indicate that as far as moral norms are concerned, it is impossible to create an indisputable justification context for them. They also indicate that a countless number of contradicting standpoints exist that cannot be used to prove, either methodologically or axiologically, the superiority of any set of moral values over other sets. Thus, we are dealing not only with an impossible to neutralize ethical relativism, but with a complete chaos of moral norms as well. There are no reliable, indisputable moral guidelines. Choosing any of such guidelines is, in a sense, an act of heroic courage, as proposed by Sartre's existentialism (Sartre, 1985, pp. 40-50). Each human is the only one responsible for each moral decision they make and its effects. Fortunately, such dilemmas practically do not concern athletes. They should not engage in any normative ethics at all. The rules of a given discipline constitute the universal benchmark for their behavior during competition.

Combining sport with morality and ascribing particular ethical values to the rules of sport disciplines is yet another failed attempt at imbuing sport activity with extra value, as is combining sport with art. Combining sport with morality is an attempt at showing that sport is something more than competition and games. In fact, in ancient Greece, sport was indeed something more than competition and games, especially in terms of the Olympic Games, which comprise particular sport disciplines. The Olympic Games also constituted a form of religious cult dedicated to ancient gods. They conducted a message characteristic for soteriological ethics. Today, the Olympic Games are a completely secularized form of extraordinary mass sport activity, as are world or continental championships in various sport disciplines. Any type of normative ethics is unnecessary because what matters is only strictly following the rules of competition (referred to as pure play) and skillfully and praxeologically (i.e., effectively) using them during play, thus working towards the assumptions and aims of a given sport activity.

I express this purposefully controversial attitude in six articles included in this work. These articles to a greater or lesser extent present my opinion on the relationship between sport and normative ethics. Each of them presents justification contexts appropriate for each subject. They were published in the previous issues of the "Physical Culture and Sport. Studies and Research". In this article, I have given my general opinion on these relationships. The other articles present my opinion in greater detail.

\section{REFERENCES}

Augustine, Contra academicos.

Augustine, De civitate Dei.

Cygan, J.M. (1993). Teologia sportu w perspektywie katolickiej /Theology of sport from the Catholic perspective/. In Z. Dziubiński (Ed.), Chrześcijańska koncepcja sportu /The Christian concept of sport/ (pp. 9-19). Warsaw: Wydawnictwo SALOS.

Feyerabend, P. (1975). Against the Method. London: Verso. 
Hume, D. (1947). Badania dotyczace rozumu ludzkiego /An enquiry concerning human understanding/. Krakow: PWN. Hume, D. (1963). Traktat o naturze ludzkiej /Treatise of Human Nature/. Warsaw: PWN.

Hume, D. (1974). Związek konieczny /On the Idea of Necessary Connection/. In Jedynak, D. (Ed.), Hume (pp. 157-159). Warsaw: PW „Wiedza Powszechna”. Jedynak, D. Hume. Warsaw: PW „Wiedza Powszechna”.

Kant, I. (2002). Groundwork for the Metaphysic of Morals. New York: Vail-Ballou Press.

Kierkegaard, S. Dziennik uwodziciela /The diary of a seducer/. In Albo, albo /Either, or/ (pp. 344-521). Warsaw: PWN. Kierkegaard, S. (1972). Bojaźń i drżenie. Choroba na śmierć/Sickness unto heath/. Warsaw: PWN.

Kosiewicz, J. (2000). Myśl wczesnochrześcijańska i katolicka wobec ciała /Attitude of Early Christian and Catholic thought towards the body/. Warsaw: Witmark.

Kosiewicz, J. (2000). Bóg, cielesność i miłość /God, corporeality and love/. Warsaw: Aletheia.

Kosiewicz, J. (1989). W poszukiwaniu sensu i źródła wartości /In search of the sense and source of values/. Człowiek $i$ Światopogląd, 1(276), 83-94.

Kosiewicz, J. (2000a). Rene Girard: źródła religii i kultury /Rene Girard: Sources of religion and culture/. In J. Kosiewicz (Ed.), Bóg, cielesność i miłość /God, corporeality and lovel. (pp. 39-62). Warsaw: Aletheia.

Kosiewicz, J. (2000c). Jurgen Moltmann - negacja nadrzędności duszy nad ciałem /Jurgen Moltmann: Negation of the superiority of the soul over the body/. In J. Kosiewicz (Ed.), Bóg, cielesność i miłość /God, corporeality and love/ (pp. 177-192). Warsaw: Aletheia.

Kosiewicz, J. (2000c). Protestantyzm wobec ciała ludzkiego /Protestantism and the human body/. In J. Kosiewicz (Ed.), Bóg, cielesność i miłość /God, corporeality and love/ (pp. 170-175). Warsaw: Aletheia.

Kosiewicz, J. (2004b). The Universals of Sport: from Realism to Nominalism. In D. Macura \& M. Hosta (Eds.), Philosophy of Sport and Other Essays. Ljubljana: Faculty of Sport, University of Ljubljana.

Kosiewicz, J. (2004). Ancient and Contemporary Olympic Games: Religious and Anthropological Aspects. In G. Anders, J. Mrazek, G. Norden \& O. Weiss (Eds.), European Integration and Sport (pp. 121-130.). Munster: LIT VERLAG Munster.

Kosiewicz, J. (2010a). Aggression in Sport. In J. Kosiewicz (Ed.), Sport and Philosophy: From Ethics to Sport (pp. 284-295). Warsaw: BK Wydawnictwo i Księgarnie.

Kosiewicz, J. (2010b). The Sporting Spectacle From the Point of View of Aleatorism. In J. Kosiewicz (Ed.), Sport and Philosophy: From Ethics to Sport (pp. 277-283). Warsaw: BK Wydawnictwo i Księgarnie.

Kosiewicz, J. (2010c). Sport Beyond Moral Good and Evil. Physical Culture and Sport. Study and Research, XLIX, 21 29. DOI: $10.2478 / \mathrm{v} 10141-010-0012-2$.

Kosiewicz, J. (2011). The Ethical Context of Justifying Anti-Doping Attitudes. Critical Reflections. Physical Culture and Sport. Study and Research, XLIII, 76-92. DOI: 10.2478/v10141-011-0024-6.

Kowalczyk, S. (2002). Elementy filozofii i teologii sportu/The Elements of Philosophy and Theology of Sport/. Sandomierz: Wyd. Seminarium.

Maritain, J. (1965). Jednostka a osoba /Individuality and personality/. In B. Baczko (Ed.), Filozofia i socjologia XX wieku /Philosophy and sociology of the 20th century/ (pp. 78-84). Warsaw: PW „Wiedza Powszechna”.

Moltmann, J. (1995). Bóg w stworzeniu /God in creation/. Krakow: Znak.

Mounier, E. (1960). Co to jest personalizm? /What is personalism?/Krakow: Znak.

Ossowska, M. (1985a). Klasyczny model moralności mieszczańskiej: Beniamin Franklin /The classical model of bourgeois morality: Benjamin Franklin/. In M. Ossowska (Ed.), Moralność mieszczańska /Bourgeois morality/ (pp. 74116). Warsaw: Ossolineum.

Ossowska, M. (1985b). Sekty purytańskie i moralność mieszczańska w rozwoju nowoczesnego kapitalizmu /Puritan cults and bourgeois morality in the development of modern capitalism/. In M. Ossowska (Ed.), Moralność mieszczańska /Bourgeois morality/ (182-226). Warsaw: Ossolineum.

Pannenberg, W. (1978). Kim jest człowiek? Współczesna antropologia w świetle teologii /What is man? Contemporary anthropology in theological perspectivel. Paris: Éditions du Dialogue.

Sartre, J.-P. (1985). Człowiek nie może uciec od odpowiedzialności /Man cannot escape from responsibility/. In: J. Kosiewicz (Ed.), Współczesna filozofia człowieka. T. 2 /Contemporary philosophy of man, vol. 2/ (pp. 40-50). Warsaw: Wyd. AWF.

Schweitzer, A. (2014). Kazania strasburskie o czci dla życia /Reverence for life: Sermons/. Toruń: Wyd. Adam Marszałek.

Thomas Aquinas, Summa theologiae. 
Thomas Aquinas, (1998). Traktat o człowieku /Treatise on Man/. In S. Świeżawski (Ed.), Summa teologii, 1 /Summa theologiae/ (pp. 75-89). Kęty: Antyk.

Weber, M. (2011). Etyka protestancka i duch kapitalizmu /The Protestant ethic and the spirit of capitalism/. Warsaw: Wydawnictwa Uniwersytetu Warszawskiego.

AUTHOR'S ADDRESS: Jerzy Kosiewicz Department of Philosophy, Chair of the Social Sciences Josef Pilsudski University of Physical Education in Warsaw 34 Marymoncka str., 00-968 Warsaw, Poland Email: jerzy.kosiewicz@awf.edu.pl 